\title{
DIGITALIZATION EFFECTS ON THE USABILITY OF LEAN TOOLS
}

\author{
Miriam Pekarčíková \\ Technical University of Kosice, Faculty of Mechanical Engineering, Institute of Management, Industrial and Digital \\ Engineering, Park Komenskeho 9, 04200 Kosice, Slovakia, EU, miriam.pekarcikova@ tuke.sk (corresponding author) \\ Peter Trebuňa \\ Technical University of Kosice, Faculty of Mechanical Engineering, Institute of Management, Industrial and Digital \\ Engineering, Park Komenskeho 9, 04200 Kosice, Slovakia, EU, peter.trebuna@tuke.sk \\ Marek Kliment \\ Technical University of Kosice, Faculty of Mechanical Engineering, Institute of Management, Industrial and Digital \\ Engineering, Park Komenskeho 9, 04200 Kosice, Slovakia, EU, marek.kliment@tuke.sk
}

Keywords: lean manufacturing, Industry 4.0, tools, impact

Abstract: Current industrial engineering methods and techniques due to the complexity of new knowledge-based methods need to be extended to technologies and tools for modelling and simulation of production processes, logistics flows, production facilities as well as product design. It is important to focus on the whole life cycle of the company as well as the product. The article deals with the effects of digitization on lean-manufacturing tools that are often used in industrial practice.

\section{Introduction}

The acceleration of ICT development has contributed to the creation of a new phenomenon - digital factory. Classical industrial engineering makes it possible to maintain competitiveness only in the short term as it is geared to address cost-optimization tasks. In the current turbulent world, it is necessary to react quickly and to see the competitiveness of the business in its customized products and services. The application of digital engineering techniques and technology to industrial practice creates the prerequisites for gaining market leadership and ensuring long-term sustainability for the future [1-5]. Westkämper highlights the professional diversity of industrial engineering in Germany and the Anglo-Saxon countries, but it reveals the potential for expanding industrial engineering in German-speaking countries. While in Germany industrial engineering is a discipline focused mainly on engineering - planning and management of production and assembly, streamlining of production technology, introduction of robotics and automation, but emphasis is placed on planning and management in Anglo-Saxon countries [6-9]. As for the Asian countries and the Pacific, industrial engineering has established itself as a discipline quite late. In 1998, the APIEMS/Asia Pacific Industrial Engineering and Management Society were established as an umbrella organization for industrial engineering from China, Japan, Korea, the Philippines, and Australia. The main emphasis is on operational research with a strong focus on informatics through simulation, modelling, artificial intelligence and algorithm development, with ergonomic aspects in the background [10].

\section{$2 \quad$ Lean tools and Industry 4.0}

To eliminate waste and losses across the value chain in a non-investment way is the philosophy of a substantial part of industrial engineering methods and tools. The aim is to get lean and high economic efficiency's processes. Waste means costs and cause the 8 basic types of loss in 4 areas, such as [11-16]:

- Preparation of production:

1. Excessive documentation - drawings, product processes, preparations, tools.

2. Search - information, documents, undelivered data files, email.

3. Waiting - for information, material.

4. Unnecessary Relocation - Information, Documentation for Signatures,

5. Lengthy process of approval, control.

6. Unnecessary operations and additional work poor processed directives, procedures, redundant information in the documentation, drawings, excess accounts, reports, duplication of the information flow.

7. Unnecessary movements - related to obtaining and clarifying information in other departments.

8. Correction and removal of errors, changes in documentation - inadequate control of production feedback.

- Production:

1. Incorrect working procedure - surplus movements and activities of the operator, resp. machine, improper operation.

2. Unnecessary movements - unnecessary manipulation and transfer of material and things not adding value, searching for material, tools, documentation, and other information. 
3. Overproduction - production in advance, resp. with a delay, production of a larger quantity than the need of the customer or the downstream process.

4. Losses on machines - dwell time (failures, planned and unplanned downtimes, alignment).

5. Waiting - material is waiting for processing, operator waiting for material - unused wait time.

6. Surplus stocks - inter-operational stocks, stocks of raw materials, auxiliary materials, finished products.

7. Correction of errors and deficiencies in quality.

8. Low motivation and support of workers in the production of proposals for improvement, low interest in decision making.

- Logistics:

1. Surplus stocks - raw materials, materials, spare parts, repairs and maintenance.

2. Overproduction - finished products of finished production

3. Waiting - for material, spare parts, information, transportation.

4. Surplus manipulation - overlaying, translating, shifting, incorrect organization of warehouses, material flows in production.

5. Searching - material, documentation, information.

6. Unnecessary actions and movements - in human work, manipulation, movement and storage.

7. Unnecessary activities - duplicate information, selection from IT systems, rewriting reports.

8. Damage to stored items - errors in ordering items, material in terms of quantity, time, location.

- Administration:

1. Excess - information, transactions, documents.

2. Waiting - for documents, transactions, creating queues in front of workstations, workstations, processing.

3. Excessive document shifts in connection with signatures, multilevel control, approval.

4. Incorrect process design - Incorrect organization of workplaces and material flows, shifts between remote workplaces, buildings.

5. Ineffective communication - complex procedures, unclear details, ignorance of procedures and IT systems.

6. Searching - information, documents, incorrect and missing data.

7. Errors and duplicities - repeated evidence, rewriting of data.

8. Untapped skills and talents of staff - insufficient motivation and support for improvement suggestions.
The beginnings of introducing lean manufacturing into serial production in the automotive industry may be dated to the post-World War II era, when Japanese manufacturers have been in a difficult position as compared to the Western ones due to lack of production resources, material, financial and working resources. One of the pioneers of lean manufacturing in Japan was Toyota's Taiichi Ohno factory manager, who "updated" Ford's waste reduction system and created the Just in Time production system. The Toyota production system differs from Ford's lean production in two fundamental principles [11-15]:

1. focus on small quantities with parameters customized to customer requirements - customization compared to the mass production of one product,

2. cast machine set-up when changing the production program according to customer requirements custom production compared to production according to market forecasts.

Lean production has become widely accepted in industrial practice in the 1980s and 1990s. It has become a very widespread approach to gaining high efficiency in enterprise production and logistics processes. In the manufacturing sector, a new paradigm of "Industry 4.0" emerged in 2011, which enable the implementation of information and communication technologies to create an intelligent network throughout the value chain, smart factory/intelligent factory. The question arises, as these two approaches are related, how they can be interconnected [17-21]. The comparison of Lean and Industry 4.0 is in Figure 1.

Based on the research of 260 applications of Industry 4.0 tools in the German industry [20,21], an analysis of the interdependence of the lean manufacturing elements with Industry 4.0 was performed. This study has shown, that lean manufacturing is a great potential for successful and sustainable deployment of Industry 4.0 to industry. Industry 4.0 essentially improves the lean manufacturing system and moves it to a much higher level. From an analysis of literary sources dealing with Industry 4.0 vs. Lean production, cited in Source [20,21], showed four interdependencies of these principles: Lean production as the basis for Industry 4.0 (2/3 authors), Industry 4.0 as Lean production, Industry 4.0 as Lean production efficiency, Industry 4.0 as a change to the Lean production principles (in connection with the integration of specific tools and industry methods 4.0). Influences Industry 4.0 and Lean tools considering the 7 types of losses are processed in Table 1. 


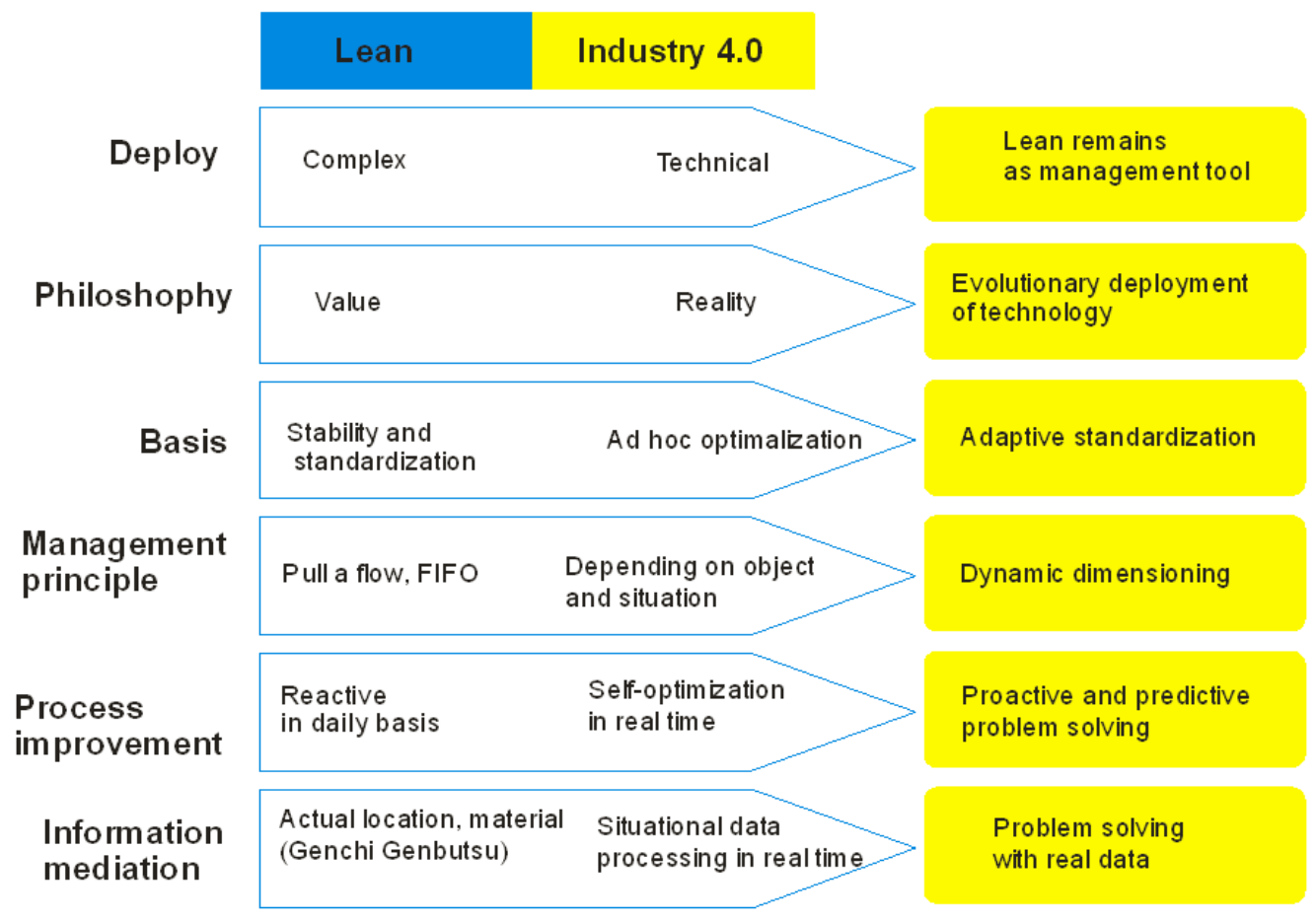

Figure 1 Comparison of Lean a Industry 4.0 [modified by 20,21]

Table 1 Matrix of length

\begin{tabular}{|c|c|c|c|c|c|c|c|c|c|c|c|c|c|c|c|}
\hline \multicolumn{2}{|c|}{ Tools } & \multicolumn{14}{|c|}{7 types of losses in production } \\
\hline \multirow{2}{*}{$\begin{array}{c}\text { Lean } \\
\text { Cell } \\
\text { production }\end{array}$} & \multirow{2}{*}{\begin{tabular}{|c|} 
Industry \\
$\mathbf{4 . 0}$
\end{tabular}} & \multicolumn{2}{|c|}{ overproduction } & \multicolumn{2}{|c|}{ transport } & \multicolumn{2}{|c|}{ moves } & \multicolumn{2}{|c|}{ waiting } & \multicolumn{2}{|c|}{ inventory } & \multicolumn{2}{|c|}{$\begin{array}{c}\text { unnecessary } \\
\text { processes }\end{array}$} & \multicolumn{2}{|c|}{ mistake } \\
\hline & & + & & + & + & + & + & + & + & + & + & & + & & \\
\hline $\begin{array}{l}\text { Reduction } \\
\text { of set up }\end{array}$ & IoT & + & + & & & & & + & + & + & + & + & & + & + \\
\hline $\begin{array}{l}\text { Quality } \\
\text { control }\end{array}$ & $\begin{array}{c}\text { Cloud } \\
\text { computing }\end{array}$ & & & & & & + & & + & + & & & + & + & \\
\hline TPM & $\begin{array}{c}\text { Data } \\
\text { analysis }\end{array}$ & & + & & + & & & + & + & & + & & & + & + \\
\hline $\begin{array}{l}\text { Production } \\
\text { balancing }\end{array}$ & 3D printing & & + & & & & & + & + & + & + & & + & & + \\
\hline Kanban & $\begin{array}{c}\text { Simulation } \\
\text { and } \\
\text { virtualizatio } \\
\mathrm{n}\end{array}$ & + & & & + & & + & + & & + & & & & & + \\
\hline $\begin{array}{c}\text { Reduction } \\
\text { of WIP }\end{array}$ & Robotics & + & & & + & & + & & + & + & & & + & & + \\
\hline $\begin{array}{c}\text { Supply } \\
\text { relationship }\end{array}$ & $\begin{array}{l}\text { Augmented } \\
\text { reality }\end{array}$ & + & & & + & & + & + & & + & & & & + & + \\
\hline Jidoka & & & & & & + & & + & & & & & & + & \\
\hline CIM & & & & & & + & & + & & & & + & & + & \\
\hline
\end{tabular}

The impact of Industry 4.0 on companies using lean manufacturing principles is not adequately explored. A concept that combines the established principles, methods and tools of lean manufacturing with information and communication technologies from Industry 4.0 is lacking. According to source [6], the first research was launched on successfully implemented projects in the automotive industry ( 24 workshops were a survey of workshops). The goal was to identify the Industry 4.0 framework for industry-leading sophisticated production systems. In the first phase, the main principles and methods were identified on the basis of lean manufacturing research. The second phase was focused on structure analysis and the identification of specific Industry 4.0 technologies. The outputs of these phases were processed into the Industry 4.0 impact matrix on Lean production systems, Table 2. The impact / synergy of Industry 4.0 with lean tools is + (+ / weak, ++ / higher, +++ / highest possible impact). 
DIGITALIZATION EFFECTS ON THE USABILITY OF LEAN TOOLS

Miriam Pekarčíková; Peter Trebuňa; Marek Kliment

Since research in this area is at the beginning, this matrix is to be understood as a dynamic framework that can be further supplemented by new knowledge.

Table 2 Matrix of impact Industry 4.0 on Lean Manufacturing [modified by 6, 13,20,21]

\begin{tabular}{|c|c|c|c|c|c|c|c|c|}
\hline \multirow{2}{*}{ Lean tools } & \multicolumn{3}{|c|}{ Data collection and processing } & \multicolumn{2}{c|}{$\begin{array}{c}\text { Communication } \\
\text { Machine-Machine }\end{array}$} & \multicolumn{2}{c|}{$\begin{array}{c}\text { Interaction } \\
\text { man - machine }\end{array}$} \\
\cline { 2 - 9 } & $\begin{array}{c}\text { Sensors } \\
\text { and } \\
\text { regulators }\end{array}$ & $\begin{array}{c}\text { Cloud } \\
\text { computing }\end{array}$ & $\begin{array}{c}\text { Big } \\
\text { data }\end{array}$ & $\begin{array}{c}\text { Data } \\
\text { analysis }\end{array}$ & \multicolumn{2}{|c|}{$\begin{array}{l}\text { Integration } \\
\text { vertical }\end{array}$} & $\begin{array}{c}\text { Virtual } \\
\text { reality }\end{array}$ & $\begin{array}{c}\text { Augmented } \\
\text { reality }\end{array}$ \\
\hline SS & + & + & + & + & + & + & ++ & +++ \\
\hline Kaizen & + & ++ & +++ & +++ & +++ & +++ & +++ & +++ \\
\hline JIT & ++ & ++ & +++ & +++ & +++ & ++ & + & ++ \\
\hline Jidoka & + & +++ & +++ & +++ & ++ & ++ & + & + \\
\hline Heijunka & ++ & ++ & +++ & +++ & +++ & ++ & ++ & + \\
\hline Standardization & ++ & +++ & +++ & +++ & ++ & ++ & +++ & +++ \\
\hline Tact & + & + & +++ & +++ & +++ & +++ & + & + \\
\hline Pull & ++ & + & + & + & +++ & +++ & + & + \\
\hline man - machine & + & + & + & + & + & + & +++ & +++ \\
\hline $\begin{array}{c}\text { People and } \\
\text { teamwork }\end{array}$ & + & + & + & + & + & + & +++ & +++ \\
\hline Reducing of & + & + & ++ & +++ & +++ & +++ & + & + \\
\hline
\end{tabular}

Initially, the introduction of lean manufacturing has eliminated waste from non-products, excess processes, time losses, inefficient movement of materials and workers, surplus stocks and overproduction. At present, it covers the entire value chain of the business, from the initial stage of the life cycle through development, supply, and production to distribution. It is a philosophy with implemented a multi-dimensional approach. Lean toolbox synergistically with digitalization creates an efficient and flexible high quality system by minimal cost.

\section{Conclusions}

The philosophy of a substantial part of industrial engineering methods is to eliminate waste and losses across the value chain. Industrial engineering applies the available tools, methods and techniques that have the greatest contribution to achievement the objectives at the lowest possible investment. The potential obvious of simulation and digital technologies largely helps in presently to manage the product lifecycle, from the process of product development through design of new resp. optimization of existing production systems.

From the above analysis, it is possible to note the great influence and compatibility of Lean tools with Industry 4.0 tools, especially in connection with Kaizen, Standardization and Tact. Kaizen is the philosophy of continuous improvement, that needs to be implemented in the enterprise so, that all employees of the company are identified with it. The goal of standardization is to stabilize processes, thereby improving productivity, quality and efficiency. Standardization of processes, procedures, production activities, logistics, etc. can be considered as one of the conditions in connection with enterprise automation process and systems, which is part of Industry 4.0. Tact is the basic indicator of Lean Manufacturing that shows how fast products are to be produced. It is especially important in terms of supply chain synchronization, which is important in terms of increasing the efficiency of processes in the dynamic of the supply chain. It is appropriate to build on the established Lean Manufacturing principles in company, to intensify its and to gradually link to Industry 4.0 tools.

\section{Acknowledgement}

This article was created by implementation of the grant project APVV-17-0258 Digital engineering elements application in innovation and optimization of production flows.

\section{References}

[1] GREGOR, T., KRAJCOVIC, M., WIECEK, D.: Smart Connected Logistics, In: Procedia Engineering. vol. 192, Transcom 2017, $12^{\text {th }}$ International Scientific Conference of Young Scientists on Sustainable, Modern and Safe Transport. High Tatras, Grand Hotel Bellevue, Slovakia. 31. 05. - 02. 06. 2017, pp. 265-270, 2017.

[2] BINASOVA, V., BUBENIK, P., DULINA, L., DURICA, L., EDL, M., KRAJCOVIC, M., MICIETA, B.: Delegate MASs for Coordination and Control of One-Directional AGV systems: a Proof-of-Concept, 
The International Journal of Advanced Manufacturing Technology, Vol. 94., No. 1-4., pp. 415-431, 2018.

[3] ČARNOGURSKÝ, K., DIAČIKOVÁ, A., ĎAŇKOVÁ, A., LACH, M.: Practical Importance of CSR in Cross-sector Cooperation, Procedia: Economics and Finance, Amsterdam: Elsevier, Vol. 34, pp. 244-251, 2015.

[4] KLOS, S., PATALAS-MALISZEWSKA, J.: The impact of ERP on maintenance management, Management and Production Engineering Review, Vol. 4, No. 3, pp. 15-25, 2013.

[5] LACIAK, M., SOFRANKO, M.: Designing of the technological line in the SCADA system PROMOTIC, Proceedings of the 2013, $14^{\text {th }}$ International Carpathian Control Conference, ICCC 2013, 2013.

[6] NASH, M., POLING, S. R.: Mapping the total value stream: A Comprehensive Guide for Production and Transactional Processes, CRC Press, New York, USA, 2008.

[7] NYHUIS, P., WIENDAHL, H-P.: Fundamentals of Production Logistics: Theory, Tools and Applications, Springer, Hannover, Germany, 2009.

[8] OTTOVA, M., KUDRNA, J., POOR, P., EDL, M.: New Possibilities of Knowledge Transfer by Playing Manager Games, Procedia - Social and Behavioural Sciences, Vol. 174, pp. 3738-3742, 2015. doi:10.1016/j.sbspro.2015.01.1107

[9] SANIUK, S., SAMOLEJOVA, A., SANIUK, A., LENORT, R.: Benefits and barriers of participation in production networks in a metallurgical cluster research results, Metalurgija, Vol. 54, No. 3, pp. 567570, 2015.

[10] Apiems - 2002 - conference, Online, Available: https://apiems.org/4th-apiems-2002conference/ [15. Dec. 2018], 2002.

[11] PASCAL D.: Lean Production Simplified, CRC Press, 2015.

[12] ROTHER, M., HARRIS, R.: Creating continuous flow, USA: The Lean Enterprise Institute, 2001.

[13] ROTHER, M., SHOOK, J.: Learning to See, USA: The Lean Enterprise Institute, 2003.
[14] GREGOR, M., HODON, R., BIŇASOVÁ, V., DULINA, L', GAŠO, M.: Design of SimulationEmulation Logistics System, Modern Machinery MM Science Journal, Vol. 2018, No. Oct., pp. 2498-2502, 2018.

[15] STRAKA, M.: Alfa, a.s. distribution logistics system, Acta Montanistica Slovaca, Vol. 15, No. 1, pp. 34-43, 2010.

[16] HUDÁK, R. V VARGA, R., HUDÁK, J., PRASLIČKA，D., BLAŽEK, J., POLÁČEK, I., KLEIN, P.: Effect of the fixation patterns on magnetic characteristics of amorphous glass-coated sensoric microwires, Proceedings of the $15^{\text {th }}$ Czech and Slovak Conference on Magnetism Košice, Slovakia, June 17-21, 2013 Acta Physica Polonica A, Vol. 126, No. 1, pp. 417-418, 2013. doi:10.12693/APhysPolA.126.417

[17] WICHER, P., STAŠ, D., KARKULA, M., LENORT, R., BESTA, P.: A computer simulation-based analysis of supply chains resilience in industrial environment, Metalurgija, Vol. 54, No. 4, 2015.

[18] STRAKA, M., MALINDZAK, D.: Algorithms of capacity balancing of printing machineries for Alfa Foils, a.s. planning system, Acta Montanistica Slovaca, Vol. 14, No. 1, pp. 98-102, 2009.

[19] ZEESHAN., S.: Improve your Business Value through Value Stream Mapping, Online, Available: https://www.linkedin.com/pulse/enhance-customervalue-through-stream-mapping-ذيثان-سيد/, [15. Dec. 2018], 2015.

[20] KOLBERG, D., ZÜHLKE, D.: Lean Automation enabled by Industry 4.0 Technologies, IFACPapersOnLine, Vol. 48, No. 3, pp. 1870-1875, 2015.

[21] WAGNER, T., HERRMANN, Ch., THIEDE, S.: Industry 4.0 Impacts on Lean Production Systems, Procedia CIRP, Vol. 63, pp. 125-131, 2017.

\section{Review process}

Single-blind peer review process. 